\title{
SYMPOSIUM
}

\section{An Anonymous Death}

\section{Five of Five Pieces}

\section{Malcolm Parker}

Received: 5 November 2013 / Accepted: 5 December 2013 /Published online: 17 May 2014

(C) Springer Science+Business Media Dordrecht 2014

\section{An Anonymous Death}

The comet, a white haired traveller, hauls its tail behind, thereby hangs its tale. Its particulate history swings away into black time as it skirts you.

A million times a million fissions, fires in Andromeda, a surge of ice across a steppe, the moon's impacted skin. Events escape their birth and move out at the roar of light, hurtling endlessly nowhere and everywhere

colliding stray worlds, spinning and groping.

At night through cat's eye domes watchmen on the world's clearest ranges

trap the begetting of suns

or discern an ancient death

when intercepted at the glass

when Diplodocus started the journey into strata

or when a hairy thing tottered erect

and stretched out tool-seeking fingers.

The watchers in the domes live half in a past older than the sun.
I tended a white haired man

and cry out for a lens to map him.

His deeds curve short of my time sputting out in a brown river carrying a wiry oarsman in a sepia photograph.

The deeds of friends are buried in a beach wired and bullet-stippled.

His sons and their sons splay out into air return for the ritual visits.

Abandoned by his acts and their witnesses he journeyed here unencumbered by reputation or attribution.

White and upright in the launch bay tended by ghosts

he rocks and straightens.

The great open space of his going is licked by dry wind as the gantries of memory shatter, peel down stripped for the last ignition and the burn out.

I see him orbiting in a room his tales sucked away. 